\title{
Investigating negotiation of meaning in EFL children with very low levels of proficiency
}

\author{
AMPARO LÁZARO-IBARROLA \& RAÚl AZPILICUETA-MARTÍNEZ* \\ Universidad Pública de Navarra
}

Received: 29/07/2014. Accepted: 12/12/2014.

\begin{abstract}
Numerous studies hold that interaction has beneficial effects on second language acquisition among adults and children in second language contexts. However, data from children learning English as a foreign language are still unavailable. In order to fill this research niche, this study examines the conversational interactions of 8 pairs of young (ages 7-8) learners of English as a foreign language while playing a game in the classroom. The objective is to document which conversational strategies these learners use and to compare them to those previously reported for other populations. The analysis of our data shows that these children negotiate significantly less than other populations but use a variety of strategies to negotiate for meaning. Also, they resort to the L1 on some occasions and use explicit correction quite often. In light of these results we will argue in favour of using these types of interactive activities in the classroom.
\end{abstract}

KEYWORDS: negotiation, interaction strategies, feedback, L1, EFL, children, communicative tasks, language acquisition.

\section{RESUMEN}

Numerosos estudios afirman que la interacción es beneficiosa para la adquisición de una segunda lengua tanto en adultos como en niños en contextos de segunda lengua. Sin embargo, aún no hay suficientes datos de niños en contexto de lengua extranjera. Por ello, este estudio recoge datos de 8 parejas de niños (7-8 años) que aprenden inglés como lengua extranjera mientras realizan un juego en el aula. El objetivo es identificar qué estrategias utilizan y compararlas con las encontradas en otros aprendices. El análisis muestra que estos niños negocian el significado menos a menudo que otras poblaciones pero utilizan estrategias variadas. También recurren a la L1 en alguna ocasión y utilizan la corrección explícita bastante a menudo. A la luz de estos resultados se defiende la utilización de tareas interactivas en el aula de lengua extranjera.

PALABRAS CLAVE: negociación, estrategias de interacción, feedback, L1, inglés lengua extranjera, tareas comunicativas, adquisición del lenguaje.

\footnotetext{
*Address for correspondence: Amparo Lázaro. Departamento de Filología y Didáctica de la Lengua, Facultad de Ciencias Humanas y Sociales, Campus de Arrosadía, Universidad Pública de Navarra, 31006 Pamplona, Spain; e-mail: amparo.lazaro@unavarra.es
} 


\section{INTRODUCTION}

The interaction hypothesis (Long, 1996) states that second language acquisition (SLA) is facilitated when conversational partners modify their interactions in order to avoid communication breakdowns. Based on this, numerous studies have demonstrated the benefits of interaction in second language contexts, not only for adults, but for child learners as well (Mackey, 2007, 2012 for a review). However, to date, only very few studies have concentrated on children in foreign language contexts (Philp \& Tognini, 2009; Tognini, 2008; Tognini \& Oliver, 2012). In order to fill this research gap, our study examines the dialogues of eight pairs of 7-to-8-year-old learners of English as a foreign language (EFL) in Spain while they are performing a communicative task in the classroom. The participants were learning English in a school context exclusively, and, given the fact that they received a very limited amount of input, their level was lower than that of those participants reported in previous studies.

Addressing this population might not only provide deeper insights into interaction research, but it can also have important pedagogical significance: children learning EFL in schools worldwide represent an enormous (and fast-growing) number of English learners (Cameron, 2003), and communicative tasks, particularly those promoting negotiated interactions, have become common place in many L2 classrooms and are "being used more frequently in school-based foreign language classrooms" (Oliver, 2002: 98). Therefore, the findings of this paper could be of great interest to make decisions about more successful practices in EFL lessons the world over.

Thus, the purpose of the present study is to investigate whether young EFL children with a very low level of competence can negotiate for meaning while performing a task in the classroom and, if they can, to provide a description of the strategies they use and to compare them to those documented for adults and children in second language contexts.

\section{LITERATURE REVIEW}

\subsection{Why is interaction beneficial?}

In order to better understand the facilitative effect of interaction on language acquisition, several authors have strived to describe this process with greater precision by focusing on a specific type of interaction: negotiation for meaning. Negotiation for meaning has been defined as "the process whereby interactions are modified between or among conversational partners to help overcome communication breakdowns (Long, 1983a, 1983b; Long \& Porter, 1985; Porter, 1986)" (Oliver, 1998: 373). In layman's terms, negotiation for meaning is what happens when two people taking part in a conversation do not (fully) understand each other. Then, in order to achieve mutual understanding, they need to repeat something, rephrase ideas in different ways, ask their conversational partners to repeat or clarify something, let them 
know if they have or have not understood, make sure that the other has understood, etc. All these conversational efforts, usually referred to as conversational adjustments, have been claimed to act as triggers for language acquisition and have been classified into three main types (for a meta-analysis, see Mackey \& Goo, 2007): modifications to achieve comprehensible input (Long, 1983b; Pica, 1987, 1992); modifications to produce comprehensible output (Swain, 1985, 1995) and, finally, provision of feedback to trigger the corresponding modifications.

In addition to the above, the authors of these studies have pointed out that while negotiating meaning the interlocutors are highly likely to (consciously or unconsciously) pay attention to the form of the language, that is, they are forced into some kind of noticing with greater or lower levels of awareness or attention. Since noticing is also a vital factor in SLA (Schmidt, 1995), it can also be added to the list of factors that make interaction beneficial.

Nevertheless, doubt can also be cast on the effectiveness of interactive activities, especially when analysing its benefits with learners who possess two limiting features: they are very young and they have a very low proficiency level. The effect of these two features will be discussed in the next section.

\subsection{Is interaction beneficial for children with low levels of competence?}

The results of interaction research from adult populations have often been applied with barely any modifications to child studies. This has been so partly because child studies are scarce and have produced mixed results (Mackey \& Silver, 2005; Mackey et al., 2007). Nonetheless, the wide disparity found between adults and children in the process of SLA (Birdsong \& Molis, 2001; Singleton \& Ryan, 2004, among many others) seems to indicate that the specific psychological, social and linguistic characteristics of childhood will also result in important differences regarding how populations of different ages interact.

When compared to adult populations, children are "less metalinguistically and sociolinguistically aware (Harley, 1986; Scarcella \& Higa, 1981). Also, children have "less developed memory heuristics, and different underlying experiences and cognitive abilities (Ervin-Tripp, 1981)" (Oliver, 1998: 373). At the same time, childhood cannot be considered as a homogeneous period; on the contrary, children develop quite fast socially and cognitively and show very different characteristics as they grow older. Following Berk (2006), childhood can be divided into three main stages according to the development of different ways of thinking: early childhood (ages 2-7), middle childhood (ages 7-11) and early adolescence (ages 12-14). Children in middle childhood (ages 7-11), the age range our learners have entered, have not developed abstract thinking completely but already think symbolically and logically and start to imagine and consider others' perspectives. From a linguistic point of view, children at this stage are becoming gradually more aware of the pragmatics of speech acts and are acquiring greater metalinguistic awareness than their younger peers (Philp et al., 
2008). Based on these features, a task as formally and cognitively demanding as interaction could be too difficult for children in early childhood but, on the contrary, it might be feasible and even beneficial for those entering middle childhood.

Leaving aside these theoretical considerations, in favour of the positive effects of interactive tasks lie the most relevant empirical studies in interactional research addressing young learners: Oliver's studies (1995a, 1995b, 1998, 2000, 2002). In these studies, she examines a large database of conversational interactions of 192 children (ages 8-13) learning English as a second language in Australia, paired together into 96 dyads. She points out that, despite the age-related limitations described above, children are able to interact and engage in conversational interaction cooperatively. When comparing the interactional patterns of children and adults she demonstrates that both populations benefit from comprehensible input, produce comprehensible output and receive feedback about their attempts. She also finds that children and adults use the same types of strategies but at different rates. The most striking difference is that children use fewer comprehension checks. This difference becomes greater when the children are younger and implies not only fewer comprehension checks but also a lower percentage of repetitions of their partners' utterances (Oliver, 2009). As Oliver (1998) explains, "possibly because of their level of development and their purported egocentric nature, primary school children tend to focus on constructing their own meaning, and less on facilitating their partners' construction of meaning" (Oliver, 1998: 379).

On the other hand, some authors have also suggested that content-based tasks might not be so useful when children are young and do not have a good command of the target language (Lyster, 2001; Lyster \& Izquierdo, 2009). Lyster (2001), in an empirical study on the provision of feedback with young students (ages 8-10) learning French in an immersion context, claims that in communicatively oriented classrooms "young L2 learners may not readily notice target-nontarget mismatches in the interactional input" (Lyster, 2001: 268). Lyster's study seems to indicate that children are perhaps able to interact but they do not interact in a way that promotes accuracy.

Regarding the level of proficiency, several authors have demonstrated that it greatly influences the amount of negotiation for meaning. When learners are more proficient they need to negotiate less because they have to face fewer communication breakdowns. Likewise, when learners are less proficient they need to negotiate more because they have greater difficulties in understanding each other (Ellis, 1985; Gass \& Varonis, 1985). Oliver (2002: 97) proposes the following classification to show that the higher the level of the interlocutors the lower the amount of negotiation $(\mathrm{H}=$ high; $\mathrm{L}=$ low; $\mathrm{NS}=$ native speaker; $\mathrm{NNS}=$ non-native speaker):

\section{L-L $>\mathrm{H}-\mathrm{L}>\mathrm{H}-\mathrm{H}>\mathrm{L}-\mathrm{NS}>\mathrm{H}-\mathrm{NS}>\mathrm{NS}-\mathrm{NS}$}


The EFL context of the present study is characterized by a lesser number of hours of exposure to the target language when compared to immersion, second language or content and language integrated learning (CLIL) contexts; as a consequence, our participants differ from those in previous research because they possess a much lower level of the target language. Thus, our results will contribute to shed new light on the value of interaction in an EFL context with children who have low proficiency levels.

\section{RESEARCH QUESTIONS}

The present study seeks to answer the following research questions:

(i) Do EFL children negotiate for meaning with their age-matched peers?

(ii) If so, what strategies do they use?

(iii) Are these results similar to the findings of adults and children in second language contexts?

Based on the theoretical background presented above we make the following prediction: as the children in the present study have entered middle childhood (thus gaining cognitive, linguistic and social abilities) and as previous studies with children in second language contexts have yielded positive results, we expect that these children will be able to negotiate for meaning with their age-matched peers and will probably use the same strategies that have been reported in previous studies.

\section{MATERIAL AND METHODS}

\subsection{Participants}

The sample consisted of 16 EFL learners (ages 7-8), paired into eight proficiency-matched dyads. The learners had different L1 backgrounds but were all living in Spain and spoke Spanish fluently. All of them had been learning English in the same school since the first year of Primary (when they turned 6). Each school year they had received five English lessons per week (around 165 hours per year). For the purposes of the present study, the proficiency of the students was judged using school-internal assessment tests. Although there were level differences among the students, all of them were real beginners and had a very low level of English: they were able to understand simple instructions in the classroom context and were also able to produce guided language at a basic level. Table 1 features these details. 


\begin{tabular}{|l|c|c|c|c|}
\hline Pair & Student & L1 & Age & Level of English \\
\hline \multirow{2}{*}{ P1 } & A & Bulgarian & 7 & Above average \\
\cline { 2 - 5 } & B & Spanish & 7 & Above average \\
\hline \multirow{2}{*}{ P2 } & A & Spanish & 7 & Average \\
\cline { 2 - 5 } & B & Romanian & 7 & Above average \\
\hline \multirow{2}{*}{ P3 } & A & Chinese & 7 & Average \\
\cline { 2 - 5 } & B & Spanish & 7 & Above average \\
\hline \multirow{2}{*}{ P4 } & A & Spanish & 7 & Average \\
\cline { 2 - 5 } & B & Bulgarian & 7 & Above average \\
\hline \multirow{2}{*}{ P5 } & A & Romanian & 8 & Above average \\
\cline { 2 - 5 } & B & Spanish & 8 & Above average \\
\hline \multirow{2}{*}{ P6 } & A & Spanish & 8 & Below average \\
\cline { 2 - 5 } & B & Spanish & 8 & Average \\
\hline \multirow{2}{*}{ P7 } & A & Bulgarian & 8 & Above average \\
\cline { 2 - 5 } & B & Romanian & 8 & Average \\
\hline \multirow{2}{*}{ P8 } & A & Spanish & 8 & Below average \\
\cline { 2 - 5 } & B & Spanish & 8 & Below average \\
\hline
\end{tabular}

Table 1. Participants

During data collection their English teacher was one of the authors of the present paper. The teaching method was that of a typical communicative classroom where all skills were integrated by making extensive use of games, songs and all sorts of communicative tasks. This researcher made the eight pairs taking into account students' relationships (and level when possible). The second author of this paper engaged in participant observation and cooperation with the regular teacher for two weeks before the data were collected in order to become familiar with the students. In addition to this, the students were video recorded several times to guarantee that the video camera did not influence their production. All in all, a great effort was made to undertake the whole study within everyday classroom conditions in order to make sure the students felt relaxed and performed as usual, which, in fact, was the case throughout the whole process.

\subsection{The Task: Guessing Game}

The dyads were video recorded playing a guessing game in the classroom. Each pair played the game three times (once per week). The two students in the pair and one researcher participated in the game. We will refer to this researcher as INV1 (investigator 1). The students sat on the floor together while INV1 stood up a few steps away from them. INV1 imagined she was an object, animal or person, and the students had to ask her questions in 
order to guess what object, person or animal she was. The elements to guess were "the head teacher", "an apple" and "a car". The participants had to talk to each other until they agreed on a specific question; then, they called INV1 and asked her their question. The interaction between the students while deciding what to ask is the object of analysis of the present study. The second researcher, to whom we will refer as INV2 (investigator 2), did not participate in the game. He simply sat on the floor next to the students to record them and to coordinate the activity. He did not speak to the children or help them with the questions, except when they got stuck, then, he helped them to move the task along by asking "so, is this the question you want to ask?", or by suggesting "would you like to move on to the next question?"

The students were allowed to formulate a total number of nine questions and were not allowed to guess before they had asked (or tried to ask) all of them. They were given the following question words written down on a piece of cardboard as prompts: Do you?; Are you?; What?; Why?; Who?; How?; Can?; How many?; Where? These question words were selected because they had been involved in games using them in the classroom for several sessions before data collection began.

No time limit was given and while one pair was performing the task, the rest of the students in the group were doing other activities, usually in the same classroom (reading, writing or playing language games together in small groups). This decision was made to fully preserve the real classroom conditions.

\subsection{Codification}

All recordings were transcribed by one of the researchers. On the whole two hours, 34 minutes and 12 seconds were transcribed. All speech signals relevant to understand the interactions were included, such as hesitations, intonation patterns of disagreement, agreement, surprise, etc., as well as contextual, non-linguistic signals, such as students pointing at a specific place or saying "yes" or "no" with a nod of the head. The second researcher checked the transcriptions against the recording searching for possible discrepancies. Inter-rater reliability was $94 \%$.

All the conversational strategies found in the learners' interactions were coded. These include conversational adjustments, repetitions, feedback and L1 use. The codification of these strategies reached an inter-rater reliability of $98 \%$. Next, a description of the codified elements is briefly provided.

\subsubsection{Conversational adjustments}

Conversational adjustments have been classified into the following types: clarification requests, confirmation checks and comprehension checks (Long, 1983a, 1983b; Oliver, 1998; Pica, 1987). Clarification requests consist of utterances in which the listener does not (fully) understand something and asks for clarification, as illustrated in Example 1. In confirmation 
checks the listener makes sure that he or she has understood the speaker's utterance correctly, as can be seen in Example 2. Finally, in comprehension checks the speaker makes sure that a previous utterance has been correctly understood by the listener, as we see in Example 3.

\section{Example 1}

NNS: A little line in the leave.

NS: A what? (Clarification request)

Example 2

NNS1: Where does the um, glasses go?

NNS2: The glasses? (Confirmation check)

Example 3

NNS: You know what, you know? (Comprehension check)

(Examples from Oliver, 1998: 375)

\subsubsection{Repetitions}

Repetitions are described as the interlocutor's repetition of lexical items from preceding utterances within five speaking turns (Pica \& Doughty, 1985). The utterances can be repeated completely, partially or by expanding them and the interlocutors can repeat their own production (self-repetition) or the other's production (other repetition). Example 4 demonstrates cases of repetitions.

Example 4

NNS: How long centimetres?

NNS: How long centimetres? (Complete self-repetition)

NNS: You know?

NNNS: How long? (Partial other repetition)

NNS: And half.

Four and a half (Expanded self-repetition).

(Examples from Oliver, 1998: 375)

\subsubsection{Feedback}

Although feedback can take a great variety of forms (Mackey, Gass, \& McDonough, 2000), in the present study only two basic forms will be considered: recasts and explicit corrections. Explicit corrections simply consist of providing the correct form in such a way that the listener is expected to easily recognise the feedback as a correction, as can be seen in Example 
5. Recasts, on the other hand, consist of target-like reformulations of the incorrect utterance maintaining the intended meaning (Long, 1996), as is shown in Example 6. In recasts, the interlocutor providing them does not explicitly indicate where the error lies or even that there is an error or that the recast is a correction (Yilmaz, 2012).

\title{
Example 5
}

Learner A: Where? Where is my birthday?

Learner B: No, that's WHEN. (Explicit correction)

(Example from our data)

\author{
Example 6 \\ Learner A: The sun is top of page. \\ Learner B: Is at the top? (Recast) \\ Learner A: Yes, is at the top. \\ (Example from Mackey et al., 2007: 286)
}

\subsubsection{L1 use}

L1 use has been profusely documented in immersion, second and foreign language contexts (Alegría de la Colina \& García-Mayo, 2009; Swain \& Lapkin, 2000) and has been recently associated with positive effects when used in peer-peer interaction among children (Tognini \& Oliver, 2012). Since the learners in the present study share a common L1, all instances in which the participants resorted to a Spanish word during their interactions were coded, as can be seen in Example 7.

\author{
Example 7 \\ Learner A: Sitting on the trineo? ("trineo" is the Spanish word for "sleigh") \\ (Example from our data)
}

\section{RESULTS AND DISCUSSION}

Table 2 presents the rate of use of conversational adjustments, repetitions, feedback and L1 words in our learners' dialogues. As in Oliver (1998), the rate represents the percentage of strategies used over the total number of utterances in the task. 


\begin{tabular}{|r|c|c|}
\hline $\begin{array}{c}\text { Strategy use over } \\
\text { number of utterances (953) }\end{array}$ & $\begin{array}{c}\text { Number } \\
\text { of instances }\end{array}$ & Percentage \\
\hline Clarification requests & 7 & 0.73 \\
\hline Confirmation checks & 4 & 0.42 \\
\hline Comprehension checks & 0 & 0 \\
\hline Conversational adjustments & $\mathbf{1 1}$ & $\mathbf{1 . 1 5}$ \\
\hline Self-repetition & 11 & 1.15 \\
\hline Other repetition & 9 & 0.94 \\
\hline Repetitions & $\mathbf{2 0}$ & $\mathbf{2 . 1 0}$ \\
\hline Recasts & 0 & 0 \\
\hline Explicit corrections & 14 & 1.46 \\
\hline Provision of corrective feedback & $\mathbf{1 4}$ & $\mathbf{1 . 4 6}$ \\
\hline L1 words & $\mathbf{5}$ & $\mathbf{0 . 5 2}$ \\
\hline Total & $\mathbf{5 0}$ & $\mathbf{5 . 2 5}$ \\
\hline
\end{tabular}

Table 2. Use of interaction strategies

In order to be able to discuss our scores in relation to previous findings, Table 3 has been constructed using the results of the current study and those presented by Oliver (1998) from SLA children and by Long (1983b) from adult learners (see Oliver, 1998: 337, Table 2). As these authors have done, in this Table (unlike in Table 2) we only show the instances of conversational adjustments and of repetitions.

\begin{tabular}{|c|c|c|c|c|c|}
\hline $\begin{array}{c}\text { Strategy use } \\
\text { over } \\
\text { total number } \\
\text { of utterances } \\
\text { (953) }\end{array}$ & $\begin{array}{c}\text { EFL } \\
\text { NNS-NNS } \\
\text { (ages 7-9) } \\
\text { L1-Spanish } \\
\text { Present Study }\end{array}$ & $\begin{array}{c}\text { ESL } \\
\text { NNS-NNS } \\
\text { (ages 8-13) } \\
\text { Different L1s } \\
\text { Oliver (1998) }\end{array}$ & $\begin{array}{c}\text { ESL } \\
\text { NNS-NS } \\
\text { (ages 8-13) } \\
\text { Oliver (2002) }\end{array}$ & $\begin{array}{c}\text { NS-NS } \\
\text { (ages 8-13) }\end{array}$ & $\begin{array}{c}\text { Oliver (2002) } \\
\text { Long (1983b) }\end{array}$ \\
\hline $\begin{array}{c}\text { Clarification } \\
\text { Requests }\end{array}$ & 0.73 & 7.71 & 8.25 & 6.50 & 10.35 \\
\hline $\begin{array}{c}\text { Confirmation } \\
\text { Checks }\end{array}$ & 0.42 & 6.27 & 12.28 & 5.06 & 18.15 \\
\hline $\begin{array}{c}\text { Comprehension } \\
\text { Checks }\end{array}$ & 0 & 1.25 & 0.59 & 0.81 & 18.15 \\
\hline $\begin{array}{c}\text { Self- } \\
\text { Repetition }\end{array}$ & 1.15 & 26.98 & 42.84 & 39.37 & 41.06 \\
\hline $\begin{array}{c}\text { Other- } \\
\text { Repetition }\end{array}$ & 0.94 & 26.27 & 45 & 34.06 & 15.09 \\
\hline
\end{tabular}

Table 3. Mean percentage of negotiation strategies used by EFL and ESL children and adults.

Before we start discussing the results of our study, it is important to note that our results cannot be compared to previous ones in a fully reliable manner because they have not been collected using the same procedure or under similar circumstances. Thus, this comparison has 
to be taken with great caution. Our only aim is to provide a tentative first insight into the similarities and differences among different populations, which could be explored in greater depth in future studies.

\subsection{Quantity}

As can be observed in Tables 2 and 3, the EFL children in the present study do use interactional strategies and, except for comprehension checks, instances of all the other types have been found. On the other hand, the overall number of strategies used by our young EFL learners is very low and clearly lower than the numbers reported for children and adults in previous studies, which include learners in NNS-NS pairings and also NS-NS interactions. This scarcity seems to contradict the results obtained by Oliver (2002), who found that the amount of negotiation was more abundant when the learners were less proficient because they had more difficulties in understanding each other. In our view, our learners barely use interaction strategies simply because they are often unable to negotiate due to their low level of proficiency. Therefore, it can now be suggested that low proficiency will mean more interaction only when the interlocutors possess a minimum or threshold level of the target language; on the contrary, if the level of the participants is not high enough the learners will be barely able to use interaction strategies in order to achieve mutual understanding. Accordingly, the production of our learners could be added at one end in the classification proposed by Oliver (2002) in order to describe the connection between amount of negotiation and proficiency. Following her terminology, we will label our learners as VL (VL=Very Low).

\section{$\underbrace{\mathrm{L}-\mathrm{L}>\mathrm{H}-\mathrm{L}>\mathrm{H}-\mathrm{H}>\mathrm{L}-\mathrm{NS}>\mathrm{H}-\mathrm{NS}>\mathrm{NS}-\mathrm{NS}}>\underbrace{\mathrm{VL}-\mathrm{VL}}$}

(Oliver, 2002)

(Present study)

Using "very low" to describe the level of our learners is important because this very basic level makes our learners different from those in previous studies and it might, as explained above, be the reason why the learners interact so little. Nevertheless, two other interpretations can be offered to account for this much lower rate of use of interaction strategies. First of all, this scarcity might be due to the nature of the task itself: formulating questions together in the guessing game might not serve to promote negotiation of meaning as much as other activities involving information gaps, such as picture placement or spot-thedifference tasks. Second, this scarcity might also be due to the EFL context in which these children are learning. In this context they do not have many chances to be exposed to or to get engaged in meaningful interactions. 


\subsection{Rates of different strategies}

\subsubsection{Conversational adjustments}

As shown in Table 2, some instances of clarification requests (see Examples 8 and 9) and of confirmation checks (see Example 10) were found in our data.

Example 8

Learner A: Do you? Do you have mmm one animal in your house?

Learner B: What? (Clarification request)

Learner A: Do you have one animal in your house?

Example 9

Learner B: How many legs is have?

Learner A: Legs or necks? (Clarification request)

Learner B: Legs.

\section{Example 10}

Learner A: How many house do you have?

Learner B: House? Yes (Confirmation check)

On the contrary, our learners never used comprehension checks. This finding goes in line with previous studies in which comprehension checks were frequently used by adults but were very rarely used by older children (0,86\%) (Oliver, 1998), and even more rarely by younger children $(0,19 \%)$ (Oliver, 2009). As it is the only speaker-generated strategy, this scarcity has been interpreted as a sign of disinterest in the listener's needs due to the egocentric nature of children.

\subsubsection{Repetitions}

Coinciding with previous studies, the repetition of an utterance was the most frequent conversational adjustment used by our learners (20 instances, 2.10\%). Regarding their function, the repetitions we found did not seem to perform the role of a conversational adjustment, as was the case with the repetitions reported by Oliver $(1998,2002)$, who referred to them as "multifunctional" (Oliver 1998: 381) and who codified them twice, that is, for both functions (as repetitions and as the corresponding conversational adjustment). In our study, the participants always used self-repetition as an answer to a confirmation check or to a clarification request made by their partner, as in Example 11. On the other hand, the learners used other repetition either to (totally or partially) repeat the question proposed by their partner, thus confirming that they accepted this question as a valid one to formulate, as in 
Example 12, or to expand this question, thus proposing a slightly different version, as in Example 13.

\section{Example 11}

Learner A: How many cars do you have?

Learner B: How many? (Clarification request)

Learner A: How many cars do you have? (Self-repetition, total)

\section{Example 12}

Learner A: Are you big?

Learner B: Are you big? (Other repetition, total)

INV1: Are you going to ask that?

Learner B: Yes.

\section{Example 13}

Learner A: What colour is your boots?

Learner B: What colour is your boots do you have? (Other repetition, expanded)

In Example 11 Learner A is using the repetition as an answer to the confirmation check, by repeating it he tries to make his proposed question clearly understood this second time. On the other hand, the use of other repetition in Example 12 serves Learner B to show his partner that he accepts the question, as we see in the next move. Finally, in Example 13 Learner B repeats the question proposed and expands it, thus offering her expanded version as a better question to ask.

\subsubsection{Corrective Feedback}

The participants provided corrective feedback to each other on 14 occasions (1.46\%). Some of these provisions are presented in Example 14. In them, capital letters are used for emphasis.

\section{Example 14}

Learner A: When is your school?

Learner A: WHERE. Where is your school? (Corrective feedback)

Learner B: Why do you come from?

Learner A: WHERE ... do you come from. (Corrective feedback)

Learner A: Why is your favourite colour?

Learner B: No, is WHAT is your favourite colour. (Corrective feedback) 
As mentioned in the theoretical background of this paper, one of the reasons why interaction is beneficial for SLA is because, while negotiating meaning, learners are likely to pay attention to the form. This seems to have been the case in these examples in which the learners explicitly focus on the correct use of the wh-forms. The children were really trying to guess the mystery elements and, in fact, they seemed to provide corrections only when they felt that their question was otherwise unintelligible. That is, the corrections were totally framed in a communicative need, in an authentic use of the language with the purpose of being understood (producing comprehensible output). Given that noticing and awareness are vital predictors of success in SLA, we conclude that these explicit corrections have the potential to be very beneficial for these learners.

In spite of the above, it must be noted that the students' ability to correct was restricted to correcting wh-forms and that all the corrections provided by our learners were explicit corrections. This means that, unlike in Oliver (2000), we did not find any recasts. Several authors have found that learners who are very young, have low levels of proficiency and are dealing with content-based tasks, as is the case of our participants, are less able to identify recasts as corrections (Lyster, 2001; Lyster \& Izquierdo, 2009). Thus, it might be the case that children with these characteristics are not only less able to interpret recasts but also less able to provide them.

Finally, the relatively abundant number of explicit corrections might have been prompted by the nature of the task and by the learning context. In this task, the children were asked to co-construct a question together and this might have led them to focus on form more frequently than in other more purely communicative activities. Also, the foreign language context in which these children are learning English might value explicit corrections more strongly than immersion or CLIL contexts where communication is often favoured over form.

\subsubsection{L1 Use}

L1 use has been included as one interactional strategy reported for children who share one common language (Tognini, 2008; Tognini \& Oliver, 2012). Example 15 illustrates one of the few occasions in which the learners resorted to a Spanish word.

\section{Example 15}

Learner B: How many años do you have? ("Años" is the Spanish word for "years".)

Learner B: años?

Learner A: años \#\# birthdays.

Following Oliver (2002), negotiation for meaning includes moves to show that mutual understanding has not been achieved as well as explicit attempts to prevent communication breakdowns. In Example 15, Learner B doesn't know the word "años" (years) in English and, 
in order to be able to formulate the question and prevent a communication breakdown, uses the Spanish term, aware that (i) his partner will understand and (ii) if his partner knows the term in English he will provide it and they will be able to co-construct the question.

In any case, the most relevant finding is that these children, in spite of their low level of competence, managed to communicate in English and only used the L1 on five occasions $(0.52 \%)$. This attitude is confirmed by their teacher, who had managed to motivate the students to use English, and who explained that, as in class, the children always tried to avoid their native language.

\subsection{Other findings}

Despite the low rates of interaction strategies it is important to note that the learners were able to communicate and to successfully complete the task. In this section we comment on some task-related strategies or behaviours that the researchers observed.

\subsubsection{Non-verbal communication}

As the learners were sitting face to face, and as happens in face-to-face communication, they made very frequent use of non-verbal signs to show agreement, disagreement, surprise, etc. In our view, the possibility of resorting to non-verbal communication probably hindered more oral production. Following Oliver, who used a barrier between the children in her information tasks, it would be very interesting to see if the results vary when the learners cannot see each other. This could either help them to produce more language or discourage them because the task could be too hard and artificial.

\subsubsection{Deciding on the validity of questions}

One common communicative exchange found in our data occurred when one student rejects the question proposed or even explains to the other why one question is not a good choice to guess the mystery element. This is illustrated in Examples 16 and 17.

\section{Example 16}

Learner A and B: How many legs is have?

INV1: I have no legs, no arms, no hands, no head, no eyes, no nose, no mouth. [several turns later]

Learner B: Can it climb?

Learner A: Is no have hands, no have arms. 


\section{Example 17}

Learner A and Learner B: Are you a animal?

INV1: No, I'm not, I'm not an animal. I have no mouth, I have no nose, I have no paws, I have no legs, I have no eyes.

[several turns later]

Learner B: What is your? Favourite food?

INV2: Would you like to ask that?

Learner A: No, is no animal, is no mouth.

These examples show how the children were really concentrating on performing the task and not simply on formulating questions at random. However, we also found that sometimes they were unable to formulate a question that made sense to guess and they simply formulated a question they knew how to construct.

\subsubsection{Child behaviour}

Finally, previous studies have reported that children are, in general, "less constrained by the strictures of the tasks" (Oliver, 2009: 148). Philp et al. (2008) describe the interactions of young learners as spontaneous and imaginative and provide an example in which one child switches quickly from the task at hand to self-entertainment and another in which a child opts simply to do what he wants to do. Likewise, in our recordings we also found some interactions that seem to be characteristic of child behaviours. The children laughed a lot and were really interested in guessing the element, which they understood as "winning." In fact, as mentioned before, they were focusing on communication and only corrected each other when they felt INV1 would not be able to understand. They wanted to guess so badly that they often plunged into premature guessing, the most extreme case being a child who keeps on trying randomly (for 'apple,' he suggests: 'egg,' 'coco,' 'banana,' 'monkey' and 'lion'). It is also interesting to mention the case of two children who answered all the questions they formulated personally before asking them to the researcher. Some extracts to illustrate this can be seen in Example 18.

\section{Example 18}

Learner B: What is your favourite colour?

Learner A: Pink.

Learner A: Who is your mum?

Learner B: Ana.

Learner A and B: How many?

Learner A: dog do you have? 
Learner B: I don't have one. Dog.

Learner A: My [unintelligible] yes, one dog.

Finally, we can clearly see in the videos how happy the children were when it was their turn to play, let alone when they managed to guess correctly! They jumped, laughed, clapped their hands and appeared to be having great fun all along.

\subsubsection{Different personalities}

It was our objective to establish linguistically even dyads while ensuring the children got along well with each other. In spite of this, some of them took on submissive or dominant roles from the beginning. It would be interesting to know the extent to which cases in which the less proficient child assumed a dominant role could limit or hinder production or use of strategies in his or her partner.

\subsubsection{Teacher Control}

Although INV2 should have limited his role to coordinate the activity, the fact that he was very used to controlling the production of his students (he was their teacher) resulted in too many interventions. In future studies the children could be left to formulate the questions on their own in order to analyse how they manage without an adult controlling what they do.

\section{CONCLUSIONS}

In the present paper we have offered a description of the interaction strategies used by young EFL learners while performing a task in the classroom and we have compared these strategies to those reported in previous studies. Thus, we have sought to contribute to the field of interaction by providing results from children in an unexplored context (EFL) regarding the quantity, variety and functions of interactional strategies and also regarding the provision of feedback and the use of the L1.

The analysis of our data has shown that these children are able to negotiate for meaning and are also able to use the main interaction strategies reported in previous studies. In spite of these similarities, an important difference has also been found: our children negotiate much less than adults and children in second language contexts. In our view, this difference might be attributed to the fact that our learners possess a much lower level of proficiency. Consequently, we have suggested that a minimum or threshold level might be necessary for interaction to occur and we have also hypothesized that learners below this level will display the lowest rates of negotiation. Once this level is achieved, negotiation rates will be higher with less proficient learners and lower with more proficient ones, as proposed by Oliver (2002). On the other hand, the fact that our learners made extensive use of non-verbal 
communication and that their teacher intervened on too many occasions might also have hindered the use of more strategies. In future studies, the influence of learners not seeing each other and also the influence of performing tasks with no teacher intervention could be investigated.

In terms of variety, these children make use of all the strategies reported in previous studies except for one: they do not use comprehension checks, that is, children do not check if their interlocutor understands them. While comprehension checks were frequent among adults, they were also scarce among children in second language contexts and even scarcer when the children were younger (ages 5-7). This difference seems to indicate a connection between this finding and age, which, in turn, is associated with a psycho-social stage of development (Oliver, 2009). Thus, the complete non-existence of comprehension checks among our EFL children (ages 7-8) makes this finding stronger and also seems to suggest that not only age but also level or learning context could be playing a role. In future studies, training children in the use of comprehension checks in order to promote more successful interaction could also constitute an interesting line of research.

Concurring with previous findings, repetitions were the most common strategy, nevertheless, unlike in Oliver (1998, 2000, 2002), our children never used this strategy performing the function of a conversational adjustment. In all cases self-repetition was used to provide an answer to a clarification request or confirmation check and, on the other hand, other repetition was used to show their acceptance or not of a question formulated by their partner in order to guess the mystery object.

Another interesting finding was that the children were able to provide explicit corrections on wh-forms to ensure successful communication. It seems that, while the guessing game has not promoted abundant interactions, it has pushed learners towards some noticing, at least of the question forms. In fact, it is our belief that the nature of the task has probably had a great impact on the type and quantity of interaction strategies in general and on the provision of explicit corrections in particular. In order to further understand the influence that the task itself has exerted on our learners' negotiations (Gass et al., 2005) it would be interesting to carry out different task types with our students and, on the other hand, to use the guessing game with students in other contexts. Also, as in this guessing game learners have to co-construct questions together, the task could be used to investigate how peer interactions can help learners to proceed through the stages of acquisition of question formation (Mackey, 1999; Pienemann et al., 2011).

Finally, it was found that the children in the present study only resorted to the L1 rarely. This finding is, in our view, worthy of interest for teachers in foreign language contexts who are sometimes reluctant to use interaction tasks because they fear that their students will tend to use their shared L1 most of the time.

In conclusion, these children have shown that, despite their limited knowledge of the target language, they are able to co-operate linguistically in the foreign language in order to 
succeed in the task. Following the interaction hypothesis we believe that their conversational efforts may have facilitated language acquisition. Nevertheless, our study has not measured if learning has actually emerged from our learners' interactions. Therefore, in future research, tailor-made tests (Swain \& Lapkin, 2001) could be designed in order to examine if the linguistic knowledge gained from negotiation instances is retained.

Finally, we believe that these types of tasks and games could be valid tools for the EFL classroom. One of the main reasons put forward to explain why students do not achieve higher levels of competence in a foreign context is that they do not have opportunities for output (production). At the same time, one of the reasons why they do not have opportunities for output is the teacher-student ratio. We suggest that part of the classroom time could be devoted to students doing communicative tasks in pairs, which would offer every learner many more chances to use English and, in turn, to learn English in a meaningful way.

\section{ACKNOWLEDGEMENTS}

First of all, we wish to thank the editors and reviewers for their insightful and constructive comments. Also, and very specially, we would like to thank the school CPEIP José María de Huarte, located in Pamplona, the Head of school, Begoña Lecea, and all the children for their willingness and generosity to participate in this project. Finally, we are grateful to Marco Llamazares and Daniel James Mee for their help in editing and proofreading This study was supported by grant FFI2012-32212 (Spanish Ministry of Economy and Competitiveness), which is hereby gratefully acknowledged.

\section{REFERENCES}

Alegría de la Colina, A. \& García Mayo, M. P. (2009). Oral interaction in task-based EFL learning: The use of the L1 as a cognitive tool. International Review of Applied Linguistics 47(3), 325345.

Berk, L. (2006). Child Development. Boston: Pearson Education.

Birdsong, D., \& Molis, M. (2001). On the evidence for maturational constraints in second-language acquisition. Journal of Memory and Language, 44, 1-15.

Ellis, R. (1985). Teacher-pupil interaction in second language development. In S. M. Gass, \& C. G. Madden (Eds.), Input in second language acquisition (pp. 69-85). Rowley, MA: Newbury House.

Ervin-Tripp, S. (1981). Social process in first and second language learning. In H. Winitz (Ed.), Native language and foreign language acquisition (pp. 33-47). New York: New York Academy of Sciences.

Gass, S. M., \& Varonis, E. M. (1985). Task variation and nonnative/nonnative negotiation of meaning. In S. M. Gass, \& C. G. Madden (Eds.), Input in second language acquisition (pp. 149-161). Rowley, MA: Newbury House.

Gass, S. M., Mackey, A. \& Ross-Feldman, L. (2005). Task-based interaction in classroom and laboratory settings. Language Learning, 55, 575-611.

Harley, B. (1986). Age in second language acquisition. Clevedon, England: Multilingual Matters.

Kubanek-German, A. (1998). Primary foreign language teaching in Europe - trends and issues. State of the art survey article. Language Teaching, 31, 193-205.

Long, M. H. (1983a). Linguistic and conversational adjustments to nonnative speakers. Studies in Second Language Acquisition, 5, 177-193. 
Long, M. H. (1983b). Native speaker/nonnative speaker conversation and the negotiation of comprehensible input. Applied Linguistics, 4, 126-141.

Long, M. H. (1996). The role of the linguistic environment in second language acquisition. In W. C. Ritchie \& T. K. Bhatia (Eds.), Handbook of Research on Language Acquisition (pp. 413-468). Academic Press, New York.

Long, M. H., \& Porter, P. A. (1985). Group work, interlanguage talk and second language acquisition. TESOL Quarterly, 19(2), 207-227.

Lyster, R. (2001). Negotiation of form, recasts, and explicit correction in relation to error types and learner repair in immersion classrooms. Language Learning, 15(Suppl. 1), 265-301.

Lyster, R., \& Izquierdo, J. (2009). Prompts vs. recasts in dyadic interaction. Language Learning, 59, 453-498.

Mackey, A. (1999). Input, interaction and second language development. An empirical study of question formation in ESL. Studies in Second Language Acquisition, 21, 557-588.

Mackey, A. (Ed.). (2007). Conversational Interaction in Second Language Acquisition: A Collection of Empirical Studies. Oxford: Oxford University Press.

Mackey, A. (2012). Input, Interaction and Corrective Feedback in L2 Classrooms. Oxford: Oxford University Press.

Mackey, A. \& Goo, J. (2007). Interaction research in SLA: A meta-analysis and research synthesis. In A. Mackey (Ed.), Conversational Interaction in Second Language Acquisition: A Collection of Empirical Studies (pp. 407-452). Oxford: Oxford University Press.

Mackey, A., \& Silver, R. (2005). Interactional tasks and English L2 learning by immigrant children in Singapore. System, 33(2), 239-360.

Mackey, A., Gass, S. M., \& McDonough, K. (2000). How do learners perceive interactional feedback? Studies in Second Language Acquisition, 22, 471-497.

Mackey, A., Kanganas, A., \& Oliver, R. (2007). Task familiarity and interactional feedback in child ESL classrooms. TESOL Quarterly, 41(2), 285-312.

Oliver, R. (1995a). Negative feedback in child NS/NNS conversation. Studies in Second Language Acquisition, 18, 459-481.

Oliver, R. (1995b). Negotiation and Feedback in Child Second Language Acquisition. (Unpublished doctoral thesis), Perth: The University of Western Australia.

Oliver, R. (1998). Negotiation of meaning in child interactions. The relationship between conversational interaction and second language acquisition. Modern Language Journal 82, 372386.

Oliver, R. (2000). Age differences in negotiation and feedback in classroom and pair work. Language Learning, 50, 119-151.

Oliver, R. (2002). The patterns of negotiation for meaning in child interactions. Modern Language Journal, 86, 97-111.

Oliver, R. (2009). How young is too young? Investigating negotiation of meaning and corrective feedback in children aged five to seven years. In A. Mackey \& C. Polio (Eds.), Multiple Perspectives on Interaction: Second Language Interaction Research in Honour of Sue M. Gass (pp. 135-156). New York: Routledge.

Oliver, R., \& Mackey, A. (2003). Interactional context and feedback in child ESL classrooms. Modern Language Journal, 87, 519-533.

Philp, J., \& Tognini, R. (2009). Language acquisition in foreign language contexts and the differential benefits of interaction. International Review of Applied Linguistics, 47, 245-266.

Philp, J., Oliver, R., \& Mackey, A. (Eds.). (2008). Child's Play: Second Language Acquisition and the Younger Learner. Amsterdam: John Benjamins.

Pica, T. (1987). SLA, social interaction, and the classroom. Applied Linguistics, 8, 3-21.

Pica, T. (1992). The textual outcomes of native speaker-non-native speaker negotiation. In C. Kramsch \& S. McConnell-Ginet (Eds.), Text and Context: Cross-disciplinary Perspectives on Language Study (pp. 198-137). Lexington, MA: D. C. Heath and Co.

Pica, T., \& Doughty, C. (1985). Input and interaction in the communicative language classroom: A comparison of teacher-fronted and group activities. In S. M. Gass \& C. G. Madden (Eds.), Input in second language acquisition (pp. 115-132). Rowley, MA, Newbury House. 
Pienemann, M., Di Biase, B., \& Kessler, J. (2011). Processability Approaches to Language Acquisition Research and Teaching. John Benjamins Publishing Co.

Porter, P. A. (1986). How learners talk to each other: Input and interaction in task-centred discussions. In R. R. Day (Ed.), Talking to learn: Conversation and second language acquisition (pp. 3556). Rowley, MA: Newbury House.

Scarcella, R. C., \& Higa, C. (1981). Input, negotiation, and age differences in second language acquisition. Language Learning, 31, 409-432.

Schmidt, R. W. (1995). Consciousness and foreign language learning: A tutorial on the role of attention and awareness in learning. In R. W. Schmidt (Ed.), Attention and Awareness in Foreign Language Learning (pp. 1-63). Honolulu: University of Hawaii Press.

Singleton, D., \& Ryan, L. (2004). Language Acquisition: The Age Factor. (2nd ed.). Clevedon: Multilingual Matters.

Swain, M. (1985). Communicative competence: Some roles of comprehensible input and comprehensible output in its development. In S. Gass, \& C. Madden (Eds.), Input in Second Language Acquisition (pp. 235-253). Rowley, MA: Newbury House.

Swain, M. (1995). Three functions of output in second language learning. In G. Cook \& B. Seidlhofer (Eds.), Principles and practice in applied linguistics: Studies in honour of H. G. Widdowson (pp. 125-144). Oxford: Oxford University Press.

Swain, M., \& Lapkin, S. (2000). Task-based second language learning: The uses of the first language. Language Teaching Research, 4, 251-274.

Swain, M. \& Lapkin, S. (2001). Focus on form through collaborative dialogue: Exploring task effects. In M. Bygate P. Skehan \& M. Swain (Eds.), Researching Pedagogic Tasks: Second Language Learning, Teaching and Testing (pp. 99-118). Harlow: Pearson Education.

Tognini, R. (2008). Interaction in languages other than English classes in Western Australian primary and secondary schools: Theory, practice and perceptions. (Unpublished Doctoral Thesis). Edith Cowan University Western Australia.

Tognini, R., \& Oliver, R. (2012). L1 use in primary and secondary foreign language classrooms and its contribution to learning. In E. Alcon \& M. P. Safont (Eds.), Language learners' discourse in instructional settings (pp. 53-78). Amersterdam: Rodopi.

Yilmaz, Y. (2012). The relative effects of explicit correction and recasts on two target structures via two communication modes. Language Learning, 62, 1134-1169. 